\title{
Relationship between perceived organizational support and work engagement in Mexican workers.
}

\section{Relación entre el apoyo organizacional percibido y el engagement laboral en trabajadores mexicanos.}

\section{(U) DSICOGENTE ISSN 0124-013}

ARTÍCULO DE

INVESTIGACIÓN

Copyright $\odot 2021$

by Psicogente

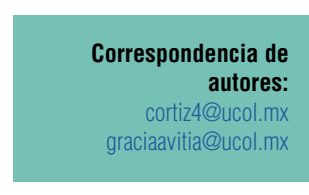

Recibido: 20-04-20 Aceptado: $03-12-20$ Publicado: 01-01-21

\author{
Cristian Jonathan Ortiz-Isabeles (iD) - César Augusto García-Avitia (iD \\ Facultad de Psicología, Universidad de Colima, Colima, México.
}

\section{Abstract}

Introduction: The organizational support and the work engagement are important elements aligned with the psychology perspective of occupational health. Understanding the interaction between both variables in a context little explored as México and Latin America give an interesting contribution to its analysis.

Objective: Analyze the relationship between perceived organizational support and work engagement in Mexican workers.

Method: Cross-sectional and correlational design were employed in this study. A regression analysis was performed on the data obtained of the Survey Perceived Organizational Support (SPOS) and Utrecht Work Engagement Scale (UWES) in their short and Spanish version. The sample consisted of 292 Mexican workers of the tertiary sector.

Results: Spearman correlation showed significant but weak correlations only between one dimension of perceived organizational support (satisfaction of socio-affective needs) and two dimensions of work engagement: vigor ( $r h o=0.33, p<0.01$ ) and dedication ( $r$ ho $=0.28, p<0.01$ ).

Conclusions: The evidence found does not support an important relationship between the two variables unlike previous studies, but those were made in different contexts to Latin America and some were related to other variables. So, it is proposed to investigate relationship of perceived organizational support with the engagement considering other variables as mediating.

Keywords: perceived organizational support, work engagement, service sector, mexican workers.

\section{Resumen}

Introducción: El apoyo organizacional y el engagement laboral son elementos importantes alineados con la perspectiva psicológica de la salud ocupacional. La comprensión de la interacción entre ambas variables en contexto poco explorado como lo es México y Latinoamérica genera un aporte interesante para su análisis.

Objetivo: Analizar la relación entre el apoyo organizacional percibido y el engagement laboral en trabajadores mexicanos.

Método: Diseño transversal y correlacional fue empleado en el estudio. Se realizó un análisis de regresión con los datos obtenidos del Cuestionario de Apoyo Organizacional Percibido (SPOS) y del Utrecht Work Engagement Scale (UWES) en sus versiones cortas y en español. El muestro fue por conveniencia y consistió en 292 trabajadores mexicanos del sector terciario.

Resultados: El análisis de correlación de Spearman mostró una correlación significativa, pero débil, entre una dimensión del apoyo organizacional percibido (satisfacción de las necesidades socioafectivas) y dos dimensiones del engagement: vigor ( $r h o=0.33, p<0.01$ ) y dedicación ( $r h o=0.28, p<0.01$ ).

Conclusiones: La evidencia encontrada no sostiene una relación importante entre ambas variables a diferencia de estudios anteriores, pero esos fueron realizados en contextos distintos al latinoamericano y algunos relacionan otras variables. Por ello se propone ahondar en la investigación de la relación del apoyo organizacional percibido con el engagement considerando otras variables como mediadoras.

Palabras clave: apoyo organizacional percibido, engagement laboral, sector de servicios, trabajadores mexicanos. 


\section{INTRODUCTION}

Occupational health is an increasingly important field in the global labor context. Since the early 2000s, psychology began to take a look at the positive aspects of human behavior under three dimensions: 1) subjective experiences, 2) individual traits and 3) the group (Seligman, 2005; Seligman \& Csikszentmihalyi, 2000).

In the new millennium, a new field called Positive Occupational Health Psychology (POHP) has arisen, seeking for better practices, structures and managements process to benefit workers' health (Salanova, 2009; Salanova, Llorens, \& Martínez, 2016). The POHP is defined as scientific research of the optimal functioning of individuals and groups' health in organizations, as well as the effective psychosocial wellbeing management at work and in development of healthy organizations (Llorens, Salanova, \& Martínez, 2008; Salanova, Martínez, \& Llorens, 2014).

Perceived organizational support (POS) and work engagement can be identified within the theorical perspective above mentioned, particularly in the subjective experiences dimension (Seligman, 2005; Seligman \& Csikszentmihalyi, 2000).

In Mexico is very important to explore perceived support and feelings of the people (like the engagement) in their workplace. For example, the reasons for abandonment of employment associated with a weak support to professional aspirations, poor working conditions and conflicts with ssupervisos have represented $61 \%$ in the last five years (Instituto Nacional de Estadística, Geografía e Informática, 2020).

The above represent different problems in organizations. When a worker does not feel good in its workplace the consecuence could culminate in organizational failure derived of increased costs and decreased productivity and quality (World Health Organization, 2010). Considering the employees needs can give financial benefits to enterprises (Henderson, 2020), even in the cases that the rotation are planned as temporary workers (De Stefano, Bonet, \& Camuffo, 2019).

\subsection{Perceived Organizational Support}

The POS can be understood as the level wich the employees feel that the organization appreciates their contribution, agrees to exchange ideas with them, and take care of their well-being (Eisenberger, Huntington, Hutchison, \& Sowa, 1986). According these authors, people with better job performance, 
lower absenteeism and higher expectations about the reward of their performance are those who perceive higher support from the organization.

This variable emerges as a construct embedded in social exchange, particularly focused on the principle of reciprocity (Armeli, Eisenberger, Fasolo, \& Lynch, 1998; Eder \& Eisenberger, 2008; Eisenberger, Armeli, Rexwinkel, D.Lynch, \& Rhoades, 2001; Eisenberger et al., 1986). Gouldner (1960) considered that people will support and will not harm those who have supported them. Support is contingent on the perceived value of the benefit received by the other. These assertions are supported by theories in moral psychology; particularly Gilligan (1985), considers justice, care, responsibility and reciprocity as values of great relevance in decision making (García-Avitia, Preciado-Serrano, Ángel-González, \& Luna Bernal, 2018).

Research done about POS has consider different variables. Some studies focused in emotional dimension have found a relationship of POS with wellbeing and satisfaction (Bogler \& Nir, 2012; Bravo-Yáñez \& JiménezFigueroa, 2011; Claudia, 2018; Eisenberger, Cummings, Armeli, \& Lynch, 1997); work stress (Foley, Hang-yue, \& Lui, 2005; Jain, Giga, \& Cooper, 2013; Stamper \& Johlke, 2003); burnout (Jawahar, Stone, \& Kisamore, 2007); and affective commitment (Abd El-Aty \& Deraz, 2018; Arshadi \& Hayavi, 2013; Aubé, Rousseau, \& Morin, 2007).

In addition, it is possible see the relevance of the POS theory has been growing through recent history of organizational psychology and has become a key aspect of occupational health. One of the purposes of this paper is to enrich the literature developed about POS. Particularly in Mexican context, the commitment have been the variable most studied in relationship whit the POS (Camacho \& Arias, 2012; Littlewood, 2003; Ojeda, Talavera, \& Berreleza, 2016, 2017; Tejada \& Arias, 2004), so seeking integration with other work variables represent a valuable contribution.

\subsection{Work engagement}

Work engagement can be defined as a cognitive-affective positive state that connects the workers to activities that they perform in their jobs feeling able to meet its demands. This feeling is persistent over time and not only focused on a specific object, situation or behavior (Salanova, Schaufeli, Llorens, Peiro, \& Grau, 2000).

The engagement began to be studied by Kahn (1990), who mentions an "engaged state" that people experience while working under great readiness to fulfill their obligations. Subsequently, some authors began to conceive 
work engagement as the counterpart of burnout syndrome (Leiter \& Maslach, 1999; Leiter \& Maslach, 2003; Maslach \& Leiter, 2001). On the other hand, Salanova et al., (2000) perspective propose that work engagement is an autonomous variable, not just the opposite side from burnout in a continuum variable.

From the last theoretical perspective mentioned, the work engagement is structured by three dimensions: vigor, dedication and absorption. Vigor refers to high levels of energy and mental resilience while people works, as well as a deep desire to carry out the activities. Dedication is about giving meaning to work, feeling inspiration, enthusiasm, pride and perceiving work as a positive challenge. Absorption is characterized by high concentration levels and experience happiness while working (Salanova et al., 2000; Schaufeli, Salanova, González-Romá, \& Bakker, 2002).

At organizational level, research shows relevant relationships between work engagement and variables like services' quality (Hernandez-Vargas, LlorensGumbau, \& Rodríguez-Sánchez, 2014), work permanence (Halbesleben \& Wheeler, 2008) and work performance (Kubota et al., 2012; Tims, Bakker, Derks, \& van Rhenen, 2013). At personal level, work engagement is related to self-efficacy (Líbano, Llorens, Salanova, \& Schaufeli, 2012; Luthans \& Peterson, 2002; Salanova, Lorente, Chambel, \& Martínez, 2011) and wellbeing (Narainsamy \& Van Der Westhuizen, 2013; Rothmann, 2008; Van der Colff \& Rothmann, 2009).

As you can see, work engagement represents a contemporary theory perfectly aligned to the occupational positive psychology (Bakker, Schaufeli, Leiter, \& Taris, 2008), with growing importance for understanding organizational development. In Mexico there are different studies about the work engagement, where the results show associations with different variables. For example, Soto-Pérez, Sánchez-García \& Núñez-Ríos (2020) watch an important modular relationship from intrinsic job satisfaction toward teacher's citizenship behavior as well as orientation towards results. Castro, De León, Acevedo, \& Ramírez (2018) identified a little effect on the resilience. Ocampo, Juárez, Arias, \& Hindrichs (2015) and Contreras (2015) stablished significative differences between variables psychosocial. Despite above, have been do not investigate the relationship with the POS, thus, another purpose of this research is adding evidence on their relevance.

\subsection{Perceived organizational support and work engagement}

Research about motivation within organizations often raises a relationship between demands and labor resources (Bakker \& Demerouti, 2007; Bakker, 
Demerouti, \& Verbeke, 2004; Demerouti, Bakker, Nachreiner, \& Schaufeli, 2001). Workers have resources, such as POS, which can be predictors of positive experiences like work engagement to their jobs (Bakker et al., 2008; Hakanen, Schaufeli, \& Ahola, 2008; Schaufeli \& Bakker, 2004; Schaufeli, Bakker, \& Van Rhenen, 2009).

There are some studies that have propose models in which POS and work engagement interact in relation with other variables (see table 1). These studies have been done mainly in Europe and Asia. Correlation $(r)$ between both variables is often seen, in different researches, as moderately strong, where the independent variable (POS) explain up to $50 \%$ of the variance according with the coefficient of determination $\left(r^{2}\right)$.

Table 1.

Previous evidence of the relationship between the perceived organizational support and work engagement.

\begin{tabular}{|c|c|c|c|c|c|c|}
\hline \multirow[t]{2}{*}{ AUTHOR } & \multirow[t]{2}{*}{ CITY } & \multirow[t]{2}{*}{$\mathbf{N}$} & \multirow[t]{2}{*}{ OCCUPATIONAL GROUP } & \multirow{2}{*}{$\begin{array}{c}\text { CORRELA- } \\
\text { TION } \\
\mathbf{R}\end{array}$} & \multicolumn{2}{|c|}{$\begin{array}{l}\text { REGRESSION } \\
\text { ANALYSIS }\end{array}$} \\
\hline & & & & & $\mathbf{R}^{2}$ & $\mathbf{P}$ \\
\hline (Sulistyo \& Suhartini, 2019) & Indonesia & 101 & Education & 0.85 & - & - \\
\hline $\begin{array}{c}\text { (Najeemdeen, Abidemi, Rahmat, \& } \\
\text { Bulus, 2018) }\end{array}$ & Malaysia & 203 & Staff academic & 0.34 & 0.35 & $<0.05$ \\
\hline $\begin{array}{c}\text { (Fouzia, Sayyid, Ishfaq, \& Madiha, } \\
\text { 2018) }\end{array}$ & Pakistan & 273 & Services workers & 0.58 & - & - \\
\hline $\begin{array}{c}\text { (Yongxing, Hongfei, Baoguo, \& Lei, } \\
\text { 2017) }\end{array}$ & China & 1094 & Customer service & 0.48 & - & - \\
\hline \multirow[t]{2}{*}{ (Mhurty, 2017) } & - & 345 & Various & 0.78 & - & - \\
\hline & & & & $V=0.43$ & 0.23 & $<0.01$ \\
\hline \multirow[t]{2}{*}{ (Wang, Liu, Zou, Hao, \& Wu, 2017) } & China & 1330 & Nurses & $D=0.44$ & 0.36 & $<0.01$ \\
\hline & & & & $A=0.34$ & 0.16 & $<0.01$ \\
\hline (Gupta, Agarwal, \& Khatri, 2016) & India & 475 & Nurses & 0.42 & 0.20 & $<0.01$ \\
\hline (Köse, 2016) & Turkey & 433 & Teachers & 0.27 & - & - \\
\hline (Dai \& Qin, 2016) & China & 301 & Various & 0.71 & 0.50 & $<0.001$ \\
\hline (Alvi, Abbasi, \& Haider, 2014) & Pakistan & 312 & Banking sector & 0.47 & 0.41 & $<0.001$ \\
\hline (Dabke \& Patole, 2014) & India & 130 & IT company & 0.51 & 0.40 & $<0.001$ \\
\hline (Mahon, Taylor, \& Boyatzis, 2014) & United States & 285 & Manufacturing and Community College & 0.59 & 0.54 & $<0.01$ \\
\hline (Shusha, 2013) & Egypt & 467 & Small factories & 0.55 & 0.31 & $<0.001$ \\
\hline (Caesens \& Stinglhamber, 2014) & Belgium & 342 & $\begin{array}{l}\text { Technologic services and banking consul- } \\
\text { tancy service }\end{array}$ & 0.33 & - & - \\
\hline (Rubel \& Kee, 2013) & Bangladesh & 150 & Industry & 0.71 & - & $<0.001$ \\
\hline \multirow{3}{*}{$\begin{array}{c}\text { (Gillet, Huart, Colombat, \& Fou- } \\
\text { quereau, 2013) }\end{array}$} & & & & $V=0.43$ & 0.55 & - \\
\hline & France & 170 & Police officers & $D=0.36$ & 0.67 & - \\
\hline & & & & $A=0.36$ & 0.61 & - \\
\hline \multirow[t]{2}{*}{ (Biswas \& Bhatnagar, 2013) } & India & 221 & Various & 0.23 & - & $<0.05$ \\
\hline & & & & $V=0.28$ & - & - \\
\hline \multirow[t]{2}{*}{ (Gokul, Sridevi, \& Srinivasan, 2012) } & India & 102 & petrochemical industry & $D=0.35$ & - & - \\
\hline & & & & $A=0.21$ & - & - \\
\hline
\end{tabular}


In addition, evidence has shown that mixing POS and work engagement can have impact in other important variables. Yongxing et al., (2017) observed the mediating role of POS between work engagement and performance. Fouzia et al., (2018) analyzed how POS, indirectly and directly, influences on citizenship behavior through wellbeing and work engagement. Another study is such by Gokul et al., (2012) who analyzed that the effect of POS and dedication on affective commitment is stronger together.

In this paper, the objective was to analyze the relationship between POS and work engagement in a context that hasn't been explored before, such as Mexico and Latin America. Research hypothesis was that: high perceived organizational support influences positively work engagement.

\section{METHOD}

\subsection{Design}

Cross-sectional and correlational design were employed in this study. The study used a convenience sampling.

\subsection{Instruments}

Survey of Perceived Organizational Support (SPOS). Scale created by Eisenberger et al. (1986), translated to Spanish by Marbeti (2001; cited by Ellenberg \& Rojas, 2007; Flores \& Gómez, 2018) with a Venezuelan sample and validated in Mexico by the authors of this study. Each item consists of a Likert scale for measurement of 7 points ranging from 1 (strongly disagree) to 7 (strongly agree). Through validation in Mexico the scale was reduced to 15 items and was divided in two factors: 1) satisfaction of socio-affective needs, consisting for the items 1, 2, 3, 4, 5, 7, 11, 12, 13 and 15; and 2) sense of recognition, composed for the items 6, 8, 9, 10 and 14. Cronbach's alpha levels were 0.92 and 0.85 respectively.

Utrecht Work engagement Scale (UWES). The questionnaire used for this research was the short version (UWES-9), which was adapted to Mexico by Hernandez-Vargas, Llorens-Gumbau, Rodriguez-Sanchez, \& DickinsonBannack (2016) with health professionals' sector. The scale is composed by 9 items divided in three sub scales: 1) vigor (items 1, 2 and 3); 2) dedication (items 4, 5 and 6); and 3) absorption (items 7, 8, 9). Each item consists of a Likert scale of six points its, ranging from 0 (never) to 5 (always / every day). Cronbach's alpha of the factors ranges from 0.84 to 0.92 . 


\subsection{Participants}

Participants for this research were workers of the tertiary sector from Colima, Mexico. The sample was selected from city downtown because of its greater number of organizations of services sector. 27 workplaces accepted to participate in the study, with a universe $(\mathrm{N})$ of 1215 workers. Participants of the sample were 292 (24.03\%) workers (130 female and 162 male), with average age of 38.71 years old $(S D=9.92)$ between 20 and 66 years. Their average years at work were $9.73(S D=8.49)$.

Schooling level corresponded mostly to bachelor's degree (47.3\%), then postgraduate (19.2\%), high school (12.3\%), technical (12\%), secondary school (8.6\%) and finally elementary school (0.7\%). Type of organizations included: trade activities (12.4\%), educational services (39.4\%), health services (16.4\%), temporary accommodation services (5.1\%), civil organization $(1.7 \%)$ and government activities (25\%).

\subsection{Procedure}

Participation in the study was requested by visiting or emailing 122 tertiary sector organizations in the city of Colima. Details about research design and ethical considerations, as confidentiality, were explained to managers. Only 35 agreed to participate and gave tentative dates to apply both surveys. By the time of apply surveys only 27 workplaces really accepted to participate. Questionnaires were applied between March and May 2019. Each worker gave its informed consent and answered the instruments voluntarily.

Inclusion criteria for this study were three: 1 ) organizations were part of the "Directorio Estadístico Nacional de Unidades Económicas" (National statistics directory of ecomomic units); 2) organizations were from Colima downtown; 3) organizations belonged to tertiary sector. On another hand, the exclusion criteria (once the questionnaires have been answered) were two: 1 ) if worker didn't reply all the items; 2 ) if answers showed logical inconsistencies.

\subsection{Analysis of data.}

Statistical Package for the Social Sciences (SPSS) version 19 was used to data analysis. Descriptive statistics were made to know distribution of scores through the average and standard deviation. Then Levene and KolmogorovSmirnov tests were performed to identify the homoscedasticity and normality of the sample, the results showed a dispersion of the variance inconstant in different occupational groups $(p<0.5)$ and a distribution asymmetric in 
the answers $(p<0.05)$. Therefore, the use of nonparametric test as Spearman correlation coefficient was took, where significance of data were consider according to $p<0.05$ and rho $> \pm 0.25$ (Udovičić, Baždarić, Bilić-Zulle, \& Petrovečki, 2007).

\section{RESULTS}

Considering that SPOS has seven points, the median is identified in the number four, so, it's possible identified a penchant toward high scores through the average. This means that majority workers perceived supported by organization. Principally in aspects of socio-affective needs, for example, item 3 (item with the highest score) reflects that most workers think that the organization where they work, supports them if they need a special favor (see table 2).

Table 2.

Descriptive analysis of SPOS items.

\begin{tabular}{|c|c|c|c|}
\hline & ITEM & M & SD \\
\hline 1 & La organización aprecia mi contribución para su progreso. & 5.39 & 1.47 \\
\hline 2 & La organización se enorgullece de mis logros en el trabajo. & 5.26 & 1.43 \\
\hline 3 & La organización está dispuesta a ayudarme cuando necesito un favor especial. & 5.68 & 1.30 \\
\hline 4 & La organización se preocupa por mi satisfacción en el trabajo. & 5.19 & 1.48 \\
\hline 5 & La organización presta atención a mis opiniones. & 5.17 & 1.46 \\
\hline 6 & La organización muestra poca preocupación por mí. & 4.37 & 1.77 \\
\hline 7 & Es posible obtener ayuda por parte de la organización cuando tengo un problema. & 5.57 & 1.30 \\
\hline 8 & Aunque yo realizara el mejor trabajo posible, la organización no se daría cuenta. & 4.39 & 1.80 \\
\hline 9 & La organización no aprecia ningún tipo de esfuerzo extra que yo haga. & 4.34 & 1.85 \\
\hline 10 & La organización no me toma en cuenta cuando realiza decisiones que me afectan directamente. & 4.40 & 1.86 \\
\hline 11 & La organización trata que mi trabajo sea lo más interesante posible. & 4.87 & 1.54 \\
\hline 12 & La organización verdaderamente toma en cuenta mis metas y mis valores. & 4.96 & 1.55 \\
\hline 13 & La organización realmente se preocupa por mi bienestar. & 5.21 & 1.46 \\
\hline 14 & Si se le presentase la oportunidad, la organización se aprovecharía de mí. & 4.55 & 1.80 \\
\hline 15 & La organización está dispuesta a hacer esfuerzos para ayudarme a desempeñar mi trabajo dando lo mejor de mí. & 5.18 & 1.41 \\
\hline
\end{tabular}

Note: items are written in Spanish as they appear in the scale.

Regard UWES results, scores were near to highest possible and with a short standard deviation. It means that there are homogenous scores but with positive bias. In other words, the most workers usually experiment an engagement state. So, it is possible identified in the sample high levels of energy, dedication on the work and maybe in lowest levels (but not negatives) concentration while they do their activities (see table 3 ). 
Table 3.

Descriptive analysis of SPOS items.

\begin{tabular}{lccc}
\hline$\#$ & ITEM & M & SD \\
\hline 1 & En mi trabajo me siento lleno de energía. & 4.26 & 0.97 \\
2 & Cuando me levanto por las mañanas tengo ganas de ir a trabajar. & 4.37 & 0.94 \\
3 & Soy fuerte y vigoroso en mi trabajo. & 4.51 & 0.78 \\
4 & Mi trabajo me inspira. & 4.46 & 0.95 \\
5 & Estoy entusiasmado con mi trabajo. & 4.51 & 0.84 \\
6 & Estoy orgulloso del trabajo que hago. & 4.75 & 0.58 \\
7 & Me "dejo llevar" por mi trabajo. & 3.89 & 1.19 \\
8 & Estoy inmerso en mi trabajo. & 4.17 & 1.03 \\
9 & Soy feliz cuando estoy absorto en mi trabajo. & 4.18 & 1.11 \\
\hline
\end{tabular}

Note: items are written in Spanish as they appear in the scale.

Table 4 reports the descriptive a correlation analysis, showing that POS has a very good relationship with their dimensions, on the other hand, work engagement has a moderate to good association with theirs. Regarding Spearman correlation between both constructs was significate $(p=0.01)$ but the size of relationship was less to 0.25 , so it may interpreted as absence of relationship (Udovičić et al., 2007).

Despite the above, correlations between Satisfaction of socio-affective needs with engagement in general was identified ( $r$ o $=0.25 ; p=0.01$ ). Other relationships with the POS dimension were with vigor ( $r$ o $=0.33 ; p=$ 0.01 ) and dedication ( $r h o=0.33 ; p=0.01$ ). Although the correlations were significant, these are poor according the grade of Spearman's coefficient mentioned.

Finally, in the analysis performed should be noted that recognition sense and absorption dimensions did not correlate with any opposing variables according to significance and correlation level required.

Table 4.

Spearman correlation analysis of the variables

\begin{tabular}{ccccccccc}
\hline & $\mathbf{M}$ & SD & $\mathbf{1}$ & $\mathbf{2}$ & $\mathbf{3}$ & $\mathbf{4}$ & $\mathbf{5}$ & $\mathbf{6}$ \\
\hline 1. Perceived Organizational Support & 4.83 & 1.12 & - & & & & & \\
2. Satisfaction of socio-affective needs & 5.26 & 1.12 & $0.83^{* *}$ & - & & & & \\
3. Recognition sense & 4.40 & 1.45 & $0.89^{* *}$ & $0.53^{* *}$ & - & & & \\
4. Engagement & 4.26 & 0.72 & $0.20^{* *}$ & $0.25^{* *}$ & 0.11 & - & & \\
5. Vigor & 4.37 & 0.78 & $0.30^{* *}$ & $0.33^{* *}$ & $0.22^{* *}$ & $0.66^{* *}$ & - & \\
6. Dedication & 4.55 & 0.74 & $0.25^{* *}$ & $0.28^{* *}$ & $0.18^{* *}$ & $0.70^{* *}$ & $0.58^{* *}$ & - \\
7. Absortion & 4.06 & 0.97 & 0.09 & $0.13^{*}$ & 0.04 & $0.92^{* *}$ & $0.41^{* *}$ & $0.52^{* *}$ \\
\hline$* 005 * * * 0.01$. & & & & & & & &
\end{tabular}




\section{DISCUSSION}

Perceived organizational support and work engagement are important variables in the knowledge body about worker's health. So, the objective of this research was to identify statistical relationship between POS and work engagement, particularly between each of their dimensions. Is relevant to emphasize that POS, unlike to other studies in Latin America, has shown a factorial structure with two dimensions (Ellenberg \& Rojas, 2007; Flores \& Gómez, 2018). This implies a novel relationship between study variables.

The main contribution of this paper was about the correlations between both variables. In general, the constructs did not show a strong relationship although it was significant. This was opposite to research realized by Sulistyo \& Suhartini (2019), Dai \& Qin (2016) and Rubel \& Kee (2013) whose similarity lie in the sample, since they all were from Asian continent. There may be different sociocultural factors that influence the relationship of variables. For example, Glazer (2006) argues that different cultures respond in different ways to the perception of social support at work, where Asians show a more collectivist, structured and stable culture than Latin Americans. Futures studies could deepen the relationship of both variables under a macro spatial perspective.

Regarding the dimensions were determined a correlation between satisfaction of socio-affective needs with vigor and dedication. This is an aspect that contributes to the understanding of the meaning of support in the affective issue to experience higher levels of energy and dedication. Possibly this may be presented in this way in considering that the tertiary sector (to which the sample of the study belongs) is immersed in activities with constant emotional demand that affects workers. Possibly this may be in this way to consider that the tertiary sector (to which the sample of the study belongs) is immersed in activities with constant emotional demand that affects workers (Prada-Ospina, 2019). The International Labour Organization (2016, p. 27) mentioned the assessment of experts from fifty four different countries about the most vulnerable occupational groups to have work-related stress, these were healthcare, education, services, finance, the retail trade, transport and construction, and the public sector in general.

Despite the above, the dimension mentioned can be considered as a variable with short correlation on work engagement in the Mexican context. So, the variables may have a better relationship if are combined with other variables. Aktar \& Pangil (2017) analyzed the mediating role of POS between the human 
resource management practices and work engagement, concluding that high POS strengthens that relationship. Mahon et al., (2014) indicated interaction between POS and emotional intelligence and their positive impact on work engagement. Results by Dai \& Qin (2016) shows that POS impact is higher when is combined with organizational identification. Wang, Liu, Zou, Hao, \& Wu (2017) and Shaheen \& Krishnankutty (2018) has pointed out that psychological capital helps to mediate between POS and work engagement. Future research lines could address relationship between both variables using other factors to broaden the perspective of interaction in Latin American context.

The results obtained are a first intent to clarify this relationship in Mexican context, their results could have an interesting resource in the develop of the organizations if are used for them. The processes of retention, promotion and implementation of health programs could be better if understand the relevance of socio-affective support in the engagement.

Finally, it is important to recognize limitations of this study. The first one has been identified about representativeness of the sample, since most of the participants belonged to the educational and health services leaving a minority to the rest of the occupations of the tertiary sector. Socio-cultural aspects are another point to note, because they were not analyzed in this study. A third point to consider is that the aim did not allow the involvement of more variables that could enrich the interactions between the POS and work engagement. Future research could take in consideration biases about the sample and lack of some mediating variables mentioned above.

\section{CONCLUSION}

This paper shows a first approach about POS and work engagement relationship in Mexican and Latin American context. In short, this research shows a positive and significant relation between the POS and work engagement in workers. Particularly, dimension of satisfaction of socio-affective needs of POS shows a significative relationship with vigor and dedication. These results could be considered to structure organizational strategies to stimulate the human capital. Future research could deepen in the value sociocultural of organizational support, also they could find other relationships that explain better the POS and engagement interaction.

Conflict of interest: The authors declare not conflict of interest in this research.

Acknowledgment: We thank to our institution and to the organizations and workers which collaborate with this research. 
Financing: The project was financed with our own resources.

\section{REFERENCES}

Abd El-Aty, Y., \& Deraz, A. (2018). The Influence of Perceived Organizational Support and Employee Advocacy on Organizational Commitment in Hotels. International Journal of Heritage, Tourism and Hospitality, 12(1), 155-170. https://doi. org/10.21608/ijhth.2018.31505

Aktar, A., \& Pangil, F. (2017). The Relationship between Employee Engagement, HRM practices and Perceived Organizational Support: Evidence from Banking Employees. International Journal of Human Resource Studies, 7(3), 1. https://doi. org/10.5296/ijhrs.v7i3.11353

Alvi, A. K., Abbasi, A. S., \& Haider, R. (2014). Relationship of Perceived Organizational Support and Employee Engagement. Sci.Int.(Lahore), 26(2), 951-954. http:// www.sci-int.com/pdf/657470018951-954--KHALIQ\%20ALVI--SS--.pdf

Armeli, S., Eisenberger, R., Fasolo, P., \& Lynch, P. (1998). Perceived organizational support and police performance: The moderating influence of socioemotional needs. Journal of Applied Psychology, 83(2), 288-297. https://doi. org/10.1037/0021-9010.83.2.288

Arshadi, N., \& Hayavi, G. (2013). The Effect of Perceived Organizational Support on Affective Commitment and Job Performance: Mediating Role of OBSE. Procedia - Social and Behavioral Sciences, 84, 739-743. https://doi.org/10.1016/j. sbspro.2013.06.637

Aubé, C., Rousseau, V., \& Morin, E. M. (2007). Perceived organizational support and organizational commitment. Journal of Managerial Psychology, 22(5), 479-495. https://doi.org/10.1108/02683940710757209

Bakker, A. B., \& Demerouti, E. (2007). The Job Demands-Resources model: state of the art. Journal of Managerial Psychology, 22(3), 309-328. https://doi. org/10.1108/02683940710733115

Bakker, A. B., Demerouti, E., \& Verbeke, W. (2004). Using the job demands-resources model to predict burnout and performance. Human Resource Management, 43(1), 83-104. https://doi.org/10.1002/hrm.20004

Bakker, A. B., Schaufeli, W. B., Leiter, M. P., \& Taris, T. W. (2008). Work engagement: An emerging concept in occupational health psychology. Work \& Stress, 22(3), 187-200. https://doi.org/10.1080/02678370802393649

Biswas, S., \& Bhatnagar, J. (2013). Mediator analysis of employee engagement: Role of perceived organizational support, p-o fit, organizational commitment and job satisfaction. Vikalpa, 38(1), 27-40. https://doi.org/10.1177/0256090920130103

Bogler, R., \& Nir, A. E. (2012). The importance of teachers' perceived organizational support to job satisfaction. Journal of Educational Administration, 50(3), 287-306. https://doi.org/10.1108/09578231211223310

Bravo-Yáñez, C., \& Jiménez-Figueroa, A. (2011). Bienestar psicológico, apoyo organizacional percibido y satisfacción laboral en funcionarios penitenciarios de Chile. Revista Española de Sanidad Penitenciaria, 13(3), 91-99. https://doi.org/10.4321/ s1575-06202011000300004

Caesens, G., \& Stinglhamber, F. (2014). The relationship between perceived organizational support and work engagement: The role of self-efficacy and its outcomes. Revue Europeenne de Psychologie Appliquee, 64(5), 259-267. https://doi. org/10.1016/j.erap.2014.08.002 
Camacho, C., \& Arias, L. (2012). Satisfacción, Apoyo y Compromiso en Profesores Mexicanos. Revista Interamericana de Psicología Ocupacional, 31(2), 120-127. http://revista.cincel.com.co/index.php/RPO/article/view/131

Cankaya, S. (2009). A comparative study of some estimation methods for parameters and effects of outliers in simple regression model for research on small ruminants. Tropical Animal Health and Production, 41(1), 35-41. https://doi.org/10.1007/ s11250-008-9151-4

Castro, L., De León, C., Acevedo, J., \& Ramírez, C. (2018). Resilience Processes, Engagement and Emotional Competencies, in Professionals Attending Elder People in Violence Situations in Saltillo, Coahuila and Monterrey, Nuevo León, Mexico. Actualidades en Psicología, 32(125), 33-50. https://doi.org/10.15517/ ap.v32i125.32528

Claudia, M. (2018). The influence of perceived organizational support, job satisfaction and organizational commitmenttoward organizational citizenship behavior (A Study of the Permanent Lecturers at University of Lambung Mangkurat, Banjarmasin). Journal of Indonesian Economy and Business, 33(1), 23. https://doi. org/10.22146/jieb.17761

Contreras, C. A. (2015). Determinación del nivel de Engagement laboral en trabajadores de una planta de producción de petróleo y gas costa afuera en México. Ciencia \& Trabajo, 17(52), 37-42. https://doi.org/10.4067/S0718-24492015000100008

Dabke, D., \& Patole, S. (2014). Predicting employee engagement: Role of perceived organizational support and perceived superior support. Tactful Management Research Journal, 3(1), 3, 1-8. https://www.academia.edu/12308399/predicting_ employee_engagement_role_of_perceived_organizational_support_and_ perceived_superior_support

Dai, K., \& Qin, X. (2016). Perceived Organizational Support and Employee Engagement: Based on the Research of Organizational Identification and Organizational Justice. Open Journal of Social Sciences, 04(12), 46-57. https://doi.org/10.4236/ jss.2016.412005

De Stefano, F., Bonet, R., \& Camuffo, A. (2019). Does losing temporary workers matter? The effects of planned turnover on replacements and unit performance. Academy of Management Journal, 62(4), 979-1002. https://doi.org/10.5465/ amj.2017.0291

Demerouti, E., Bakker, A. B., Nachreiner, F., \& Schaufeli, W. B. (2001). The job demands-resources model of burnout. Journal of Applied Psychology, 86(3), 499-512. https://doi.org/10.1037/0021-9010.86.3.499

Eder, P., \& Eisenberger, R. (2008). Perceived organizational support: Reducing the negative influence of coworker withdrawal behavior. Journal of Management, 34(1), 55-68. https://doi.org/10.1177/0149206307309259

Eisenberger, R., Armeli, S., Rexwinkel, B., D.Lynch, P., \& Rhoades, L. (2001). Reciprocation of POS. Journal of Applied Psychology, 86(3), 42-51. https://doi. org/10.1037//0021-9010.86.1.42

Eisenberger, R., Cummings, J., Armeli, S., \& Lynch, P. (1997). Perceived organizational support, discretionary treatment, and job satisfaction. Journal of Applied Psychology, 82(5), 812-820. https://doi.org/10.1037/0021-9010.82.5.812

Eisenberger, R., Huntington, R., Hutchison, S., \& Sowa, D. (1986). Perceived Organizational Support. Journal of Applied Psychology, 71, 500-507. https://doi. org/10.1037/0021-9010.71.3.500

Ellenberg, D., \& Rojas, J. (2007). Influencia de la identificación con el trabajo, la percepción de apoyo organizacional, la antigüedad, el sexo, la edad y el nivel de instrucción sobre la ciudadanía organizacional (Universidad Católica Andres 
Bello). http://biblioteca2.ucab.edu.ve/anexos/biblioteca/marc/texto/AAQ9997. pdf

Flores, J., \& Gómez, I. (2018). Apoyo organizacional percibido y compromiso organizacional en una empresa privada de Lima, Perú. Ajayu, 16(1), 10-30. http://hdl. handle.net/10757/624012

Foley, S., Hang-yue, N., \& Lui, S. (2005). The Effects of Work Stressors, Perceived Organizational Support, and Gender on Work-Family Conflict in Hong Kong. Asia Pacific Journal of Management, 22(3), 237-256. https://doi.org/10.1007/s10490005-3568-3

Fouzia, H. A., Sayyid, S. R., Ishfaq, A., \& Madiha, R. (2018). Effects of perceived organizational support on organizational citizenship behavior-Sequential mediation by well-being and work engagement. Journal of the Punjab University Historical Society, 31(2), 61-71. http://pu.edu.pk/images/journal/HistoryPStudies/PDF_ Files/06_v31_2_july2018.pdf

García-Avitia, C. A., Preciado-Serrano, M. L., Ángel-González, M., \& Luna Bernal, A. C. A. (2018). El desarrollo moral y la toma de decisiones éticas del psicólogo. Investigación y práctica en psicología del desarrollo, 1-28. https://doi.org/10.33064/ ippd41993

Gillet, N., Huart, I., Colombat, P., \& Fouquereau, E. (2013). Perceived organizational support, motivation, and engagement among police officers. Professional Psychology: Research and Practice, 44(1), 45-56. https://doi.org/10.1037/ a0030066

Gilligan, C. (1985). La moral y la teoría. Psicología del desarrollo femenino. México: Fondo de Cultura Económica.

Glazer, S. (2006). Social support across cultures. International Journal of Intercultural Relations, 30, 605-622. https://doi.org/10.1016/j.ijintrel.2005.01.013

Gokul, A., Sridevi, G., \& Srinivasan, P. T. (2012). The relationship between perceived organizational support, work engagement and affective commitment. AMET International Journal of Management, (2001), 29-37. http://ametjournal.com/ attachment/ametjournal-4/Dev-Article-4-Gokul.pdf

Gouldner, A. W. (1960). "The Norm of Reciprocity: A Preliminary Statement", American Sociological Review. American Sociological Review, 25(4), 161-178. https://doi.org/10.2307/2092623

Gupta, V., Agarwal, U. A., \& Khatri, N. (2016). The relationships between perceived organizational support, affective commitment, psychological contract breach, organizational citizenship behaviour and work engagement. Journal of Advanced Nursing, 72(11), 2806-2817. https://doi.org/10.1111/jan.13043

Hakanen, J. J., Schaufeli, W. B., \& Ahola, K. (2008). The Job Demands-Resources model: A three-year cross-lagged study of burnout, depression, commitment, and work engagement. Work \& Stress, 22(3), 224-241. https://doi. org/10.1080/02678370802379432

Halbesleben, J. R. B., \& Wheeler, A. R. (2008). The relative roles of engagement and embeddedness in predicting job performance and intention to leave. Work \& Stress, 22(3), 242-256. https://doi.org/10.1080/02678370802383962

Hernández-Vargas, C. I., Llorens-Gumbau, S., \& Rodríguez-Sánchez, A. M. (2014). Empleados saludables y calidad de servicio en el sector sanitario: un estudio de caso. Anales de Psicología, 30(1). https://doi.org/10.6018/analesps.30.1.143631

Hernández-Vargas, C., Llorens-Gumbau, S., Rodríguez-Sánchez, A. M., \& Dickinson-Bannack, M. E. (2016). Validación de la escala UWES-9 en profesionales de la salud en México. Pensamiento Psicológico, 14(2), 89-100. https://doi. org/10.11144/javerianacali.ppsi14-2.veup 
Henderson, M. (2020). The economic case for meeting employees' needs. Journal of Nursing Management, 28(1), 17-23. https://doi.org/10.1111/jonm.12897

Instituto Nacional de Estadística, Geografía e Informática. (2020). Encuesta Nacional de Ocupación y Empleo (ENOE), población de 15 años y más de edad. https:// www.inegi.org.mx/programas/enoe/15ymas/default.html\#Tabulados

International Labour Organization. (2016). Global trends and foresight of future scenarios. Workplace Stress: A Collective Challenge, First, pp. 2-57. https:// www.ilo.org/wcmsp5/groups/public/---ed_protect/---protrav/---safework/ documents/publication/wcms_466547.pdf

Jain, A. K., Giga, S. I., \& Cooper, C. L. (2013). Perceived organizational support as a moderator in the relationship between organisational stressors and organizational citizenship behaviors. International Journal of Organizational Analysis, 21(3), 313-334. https://doi.org/10.1108/IJOA-Mar-2012-0574

Jawahar, I. M., Stone, T. H., \& Kisamore, J. L. (2007). Role conflict and burnout: The direct and moderating effects of political skill and perceived organizational support on burnout dimensions. International Journal of Stress Management, 14(2), 142-159. https://doi.org/10.1037/1072-5245.14.2.142

Kahn, W. A. (1990). Psychological Conditions of Personal Engagement and Disengagement at Work. Academy of Management Journal, 33(4), 692-724. https://doi. org/10.5465/256287

Köse, A. (2016). The Relationship between Work Engagement Behavior and Perceived Organizational Support and Organizational Climate. Journal of Education and Practice, 7(27), 42-52. www.iiste.org

Kubota, K., Shimazu, A., Kawakami, N., Takahashi, M., Nakata, A., \& Schaufeli, W. B. (2012). [the Empirical Distinctiveness of Work Engagement and Workaholism Among Hospital Nurses in Japan: the Effect on Sleep Quality and Job Performance]. Ciencia \& Trabajo: C\&T, 13(41), 152-157. http://www.ncbi.nlm.nih. gov/pubmed/26752805\%0Ahttp://www.pubmedcentral.nih.gov/articlerender. fcgi?artid=PMC4705841

Leiter, M. P., \& Maslach, C. (2003). Areas of worklife: A structured approach to organizational predictors of job burnout. In P. Perrewe \& D. Ganster (Eds.), Emotional and Physiological Processes and Positive Intervention Strategies (3rd ed., pp. 91-134). https://doi.org/10.1016/S1479-3555(03)03003-8

Leiter, M., \& Maslach, C. (1999). Six areas of worklife: a model of the organizationalcontext of burnout. Journal of Health and Human Services Administration, 21(4), 472-489. www.jstor.org/stable/25780925

Líbano, M. Del, Llorens, S., Salanova, M., \& Schaufeli, W. B. (2012). About the Dark and Bright Sides of Self-efficacy: Workaholism and Work Engagement. The Spanish Journal of Psychology, 15(2), 688-701. https://doi.org/10.5209/rev_SJOP.2012. v15.n2.38883

Littlewood, H. (2003). Metanálisis del apoyo organizacional percibido y compromiso organizacional en organizaciones mexicanas. Revista Interamericana de Psicología Ocupacional, 22(2), 45-56. http://revista.cincel.com.co/index.php/RPO/ article/view/46

Llorens, S., Salanova, M., \& Martínez, I. (2008). Psicología de la salud ocupacional positiva: concepto y metodología para su evaluación. In J. Tous, M. A. Carrión, \& F. López (Eds.), Colección Psicología de la Salud Ocupacional' (pp. 88-108). http:// www.want.uji.es/download/psicologia-de-la-salud-ocupacional-positiva-concepto-y-metodologia-para-su-evaluacion / 
Luthans, F., \& Peterson, S. J. (2002). Employee engagement and manager selfefficacy. Journal of Management Development, 21(5), 376-387. https://doi. org/10.1108/02621710210426864

Mahon, E. G., Taylor, S. N., \& Boyatzis, R. E. (2014). Antecedents of organizational engagement: Exploring vision, mood and perceived organizational support with emotional intelligence as a moderator. Frontiers in Psychology, 5(NOV), 1-11. https://doi.org/10.3389/fpsyg.2014.01322

Maslach, C., \& Leiter, M. P. (2001). Job Burnout. Encyclopedia of Mental Health: Second Edition, 52, 222-227. https://doi.org/10.1016/B978-0-12-3970459.00149-X

Mhurty, R. (2017). Perceived organizational support and work engagement. International Journal of Organizational Analysis, 3(5), 738-740. https://doi.org/10.1108/ ijoa-11-2012-0627

Najeemdeen, I. S., Abidemi, B. T., Rahmat, F. D., \& Bulus, B. D. (2018). Perceived Organizational Culture and Perceived Organizational Support on Work Engagement. Academic Journal of Economic Studies, 4(3), 199-208. https://ideas.repec.org/a/ khe/scajes/v4y2018i3p199-208.html

Narainsamy, K., \& Van Der Westhuizen, S. (2013). Work Related Well-Being: Burnout, Work Engagement, Occupational Stress and Job Satisfaction Within a Medical Laboratory Setting. Journal of Psychology in Africa, 23(3), 467-474. https://doi. org/10.1080/14330237.2013.10820653

Ocampo, R., Juárez, A., Arias, L., \& Hindrichs, I. (2015). Factores psicosociales asociados a engagement en empleados de un restaurante de Morelos, México. Liberabit, 21(2), 207-219. http://www.scielo.org.pe/pdf/liber/v21n2/a04v21n2. pdf

Ojeda, M., Talavera, R., \& Berreleza, M. (2016). Análisis de la relación entre compromiso organizacional y percepción de apoyo organizacional en docentes universitarios. Sistemas, Cibernética e Informática, 13(1), 66-71. http://www. iiisci.org/journal/cv\$/risci/pdfs/xa510qf15.pdf

Ojeda, M., Talavera, R., \& Berreleza, M. (2017). Estudio del Tipo y Grado de Compromiso Organizacional y su Relación con la Percepción de Apoyo Organizacional en la Industria Hotelera en la Ciudad de Tijuana, México. Informática, 14(3), 118-130. http://www.iiisci.org/journal/CV\$/risci/pdfs/CA139ZP17.pdf

Prada-Ospina, R. (2019). Social psychological factors and their relation to work-related stress as generating effect of burnout. Interdisciplinaria, 36(2), 39-53. https://doi.org/10.16888/interd.2019.36.2.3

Rothmann, S. (2008). Job satisfaction, occupational stress, burnout and work engagement as components of work-related wellbeing. SA Journal of Industrial Psychology, 34(3). https://doi.org/10.4102/sajip.v34i3.424

Rubel, M. R. B., \& Kee, D. M. H. (2013). Perceived support and employee performance: The mediating role of employee engagement. Life Science Journal, 10(4), 2557-2567. http://www.lifesciencesite.com/lsj/life1004/342_2186 8life1004_2557_2567.pdf

Salanova, M. (2009). Organizaciones Saludables: Una aproximación desde la Psicologia Positiva. In C. Vázquez \& G. Hervás (Eds.), Psicología Positiva Aplicada. http://www.integraorg.com/wp-content/docs/organizaciones saludables.pdf

Salanova, M., Llorens, S., \& Martínez, I. M. (2016). Aportaciones desde la Psicología Organizacional Positiva para desarrollar Organizaciones Saludables y Resilientes. Papeles del Psicólogo / Psychologist Papers, 37(3), 177-184. http://www.papelesdelpsicologo.eshttp//www.psychologistpapers.com 
Salanova, M., Lorente, L., Chambel, M. J., \& Martínez, I. M. (2011). Linking transformational leadership to nurses' extra-role performance: the mediating role of self-efficacy and work engagement. Journal of Advanced Nursing, 67(10), 2256-2266. https://doi.org/10.1111/j.1365-2648.2011.05652.x

Salanova, M., Martínez, I. M., \& Llorens, S. (2014). Una mirada más "positiva" a la salud ocupacional desde la psicología organizacional positiva en tiempos de crisis: Aportaciones desde el equipo de investigación WoNT. Papeles del Psicólogo, 35(1), 22-30. https://www.redalyc.org/articulo.oa?id=77830184004

Salanova, M., Schaufeli, W. B., Llorens, S., Peiro, J. M., \& Grau, R. (2000). Desde el "burnout" al "engagement": ¿una nueva perspectiva? Revista de Psicología del Trabajo y de las Organizaciones, 16(2), 117-134. Retrieved from https://journals. copmadrid.org/jwop/files/63236.pdf

Schaufeli, W. B., \& Bakker, A. B. (2004). Job demands, job resources, and their relationship with burnout and engagement: a multi-sample study. Journal of Organizational Behavior, 25(3), 293-315. https://doi.org/10.1002/job.248

Schaufeli, W. B., Bakker, A. B., \& Van Rhenen, W. (2009). How changes in job demands and resources predict burnout, work engagement, and sickness absenteeism. Journal of Organizational Behavior, 30(7), 893-917. https://doi.org/10.1002/ job.595

Schaufeli, W. B., Salanova, M., González-Romá, V., \& Bakker, A. (2002). The Measurement of Engagement and Burnout: a Two Sample Confirmatory Factor Analytic Approach. Journal of Happiness Studies, 3(1), 71-92. https://doi. org/10.1023/A:1015630930326

Seligman, M. (2005). La auténtica felicidad (M. Diago \& A. Debrito, Trads.). In La auténtica felicidad (M. Diago \& A. Debrito, Trads.). https://doi.org/10.1016/j. pse.2016.11.001

Seligman, M. E., \& Csikszentmihalyi, M. (2000). Positive psychology. An introduction. The American Psychologist, 55, 5-14. https://doi.org/10.1037/0003-066X.55.1.5

Shaheen, M., \& Krishnankutty, R. (2018). The Mediation of Psychological Capital in the Relationship of Perceived Organizational Support, Engagement and Extra-Role Performance. International Journal of Knowledge Management, 14(4), 30-45. https://doi.org/10.4018/IJKM.2018100103

Shusha, A. A. (2013). The Role of Psychological Engagement in Relationship between Perceived Organizational Support and Withdrawal Behavior and Intentions: An Empirical Study on Small Industries in Egypt. International Journal of Business and Management, 8(16), 22-29. https://doi.org/10.5539/ijbm.v8n16p22

Soto-Pérez, M., Sánchez-García, J., \& Núñez-Ríos, J. (2020). Factors to improve job performance and school effectiveness. International Journal of Educational Management, 34(5), 805-822. https://doi.org/10.1108/IJEM-07-2019-0237

Stamper, C. L., \& Johlke, M. C. (2003). The Impact of Perceived Organizational Support on the Relationship Between Boundary Spanner Role Stress and Work Outcomes. Journal of Management, 29(4), 569-588. https://doi.org/10.1016/ S0149-2063_03_00025-4

Sulistyo, A. R., \& Suhartini, S. (2019). The Role of Work Engagement in Moderating the Impact of Job Characteristics, Perceived Organizational Support, and Self-Efficacy on Job Satisfaction. Integrated Journal of Business and Economics, 3(1), 15. https://doi.org/10.33019/ijbe.v3i1.112

Tejada, J., \& Arias, F. (2004). Administración de la Calidad: prácticas organizacionales percibidas y el compromiso de los trabajadores hacia la organización. Revista Interamericana de Psicología Ocupacional, 23(2), 59-70. https://www.redalyc. org/pdf/395/39520002.pdf 
Tims, M., Bakker, A. B., Derks, D., \& van Rhenen, W. (2013). Job Crafting at the Team and Individual Level. Group \& Organization Management, 38(4), 427-454. https:// doi.org/10.1177/1059601113492421

Udovičić, M., Baždarić, K., Bilić-Zulle, L., \& Petrovečki, M. (2007). What we need to know when calculating the coefficient of correlation? Biochemia Medica, 17(1), 10-15. https://hrcak.srce.hr/12855

Van der Colff, J. J., \& Rothmann, S. (2009). Occupational stress, sense of coherence, coping, burnout and work engagement of registered nurses in South Africa. SA Journal of Industrial Psychology, 35(1). https://doi.org/10.4102/sajip.v35i1.423

Wang, X., Liu, L., Zou, F., Hao, J., \& Wu, H. (2017). Associations of Occupational Stressors, Perceived Organizational Support, and Psychological Capital with Work Engagement among Chinese Female Nurses. BioMed Research International, 17, 1-11. https://doi.org/10.1155/2017/5284628

World Health Organization. (2010). WHO Healthy Workplace Framework and Model: Background and Supporting Literature and Practices (p. 137). https://www.who. int/occupational_health/healthy_workplace_framework.pdf

Yongxing, G., Hongfei, D., Baoguo, X., \& Lei, M. (2017). Work engagement and job performance: The moderating role of perceived organizational support. Anales de Psicología, 33(3), 708-713. https://doi.org/10.6018/analesps.33.3.238571

Esta obra está bajo: Creative commons attribution 4.0 international license. El beneficiario de la licencia tiene el derecho de copiar, distribuir, exhibir y representar la obra y hacer obras derivadas siempre y cuando reconozca y cite la obra de la forma especificada por el autor o el licenciante.

\section{(cc) BY}

